The second exhibit consisted of ammonites and other fossils derived from rocks similar to those seen on the northern shores of the Moray Firth at Brora and Ethie. The north-westerly derivation of these fossils is substantiated by other erratics in this the lower boulder-clay of Banffshire.

\title{
CORRESPONDENCE.
}

\section{THE PLEISTOCENE SUCCESSION IN THE TRENT BASIN.}

SIR,-I am glad to see that Professor Sollas is of opinion that recent continental work supports the view that there were four cold stages-Gunz, Mindel, Riss, and Würm-in Pleistocene times, and that these cold periods were separated by warm intervals.

In a paper on "The Pleistocene Succession in the Trent Valley" (Q.J.G.S., vol. xlii, 1886, p. 437) I showed that the positions occupied by the boulder clays and outwash gravels were such as to indicate several distinct glaciations.

The Trent Valley deposits in the neighbourhood of Burton and Derby, especially the outwash gravels and sands, would appear to be arranged very much as they are at Basle on the Rhine; the high level gravel at Spondon being Gunz, the Chellaston Hill sand, etc., Mindel, the high level gravel at Weston-on-Trent Riss, and the lower terrace of the Trent and Derwent, Würm and Riss-Würm.

In the paper on the deposits of the Trent valley referred to I made the outwash gravels of the Cheshire plain what would now be called Mindel. Since then I have come to regard them as being formed by the Wurm ice after it had receded from the Trent Valley area. The ice would appear to have lingered against the watershed, formed a marked terrace of outwash gravel on the Cheshire side, thrown great quantities of gravel, sand, etc., into the Trent Basin over low passes, and formed to some extent the lower terrace of the Trent area.

The ice of the Würm glaciation appears to have pushed its way in an easterly direction as far as Burton-on-Trent, and, perhaps temporarily, covered Sinfin Moor near Derby, local snowfields occupying the valleys to the east. West of Burton-on-Trent the Riss and Würm ice has carried away all the upper terraces.

There is nothing to prove or disprove the suggestion that the sea-level in the Trent area varied during these climatic changes. The deposits may have been largely formed in extra-glacial lakes, but whether the impounding of the water of these lakes was assisted by changes of sea-level is uncertain.

'Intagil, Kew Gardens RoAd, R. M. Deeley. KEW, SURREY.

17th January, 1923. 